\title{
Skal leger gi omsorg?
}

\author{
Gir leger omsorg, eller er omsorg noe som kun hører til pleiefag? Legers omsorg for pasienten er lite \\ beskrevet og undersøkt. Det er på tide å få omsorgen frem i lyset.
}

Begreper som empati, pasientsentrering og motoverføringer blir flittig benyttet for å beskrive forholdet mellom lege og pasient. Omsorg, derimot, er knyttet til pleiefag. Men gir ikke leger omsorg? Når en pasient søker behandling for et kutt $i$ hånden, stiller han med en forventning om en faglig vurdering og riktig behandling, men ønsker han ikke samtidig at behandlingen blir utført på en hensynsfull måte? For meg er omsorgen til stede i måten jeg tilpasser behandlingen til det enkelte mennesket og situasjonen. Den ligger i de små detaljene, i blikk og ordvalg, bevegelser og berøringer. Den avkrever tid og ressurser, og utgjør en kvalitet som støtter pasienten gjennom sykdommen. I eksemplet over vil det å sette sutur, rense såret og gi stivkrampevaksine representere noe vi tradisjonelt kaller behandling. Det å vente til bedøvelsen virker og vaske etter at anestesien er satt, tilhører kanskje omsorgen. Men deler andre leger dette synet?

\section{«Sjelden kurere, \\ ofte lindre, alltid trøste»}

Denne frasen er velkjent for mange. Den har hengt ved vår profesjon siden antikken og indikerer fortsatt at trøst og lindring er en del av gjerningen. Legers omsorg handler kanskje om dette: Ofte lindre, alltid trøste.

Omsorg i en medisinsk sammenheng er lite beskrevet og knapt undersøkt empirisk. Begrepet er vanskelig å definere og varierer med sammenhengen det benyttes i. Andre fagdisipliner har imidlertid studert omsorgen inngående. Sykepleievitenskapen bidro til å skape et skille mellom behandling og omsorg (1). Mens behandlingen bar med seg en forventning om kur og helbredelse, var omsorgsarbeideren opptatt av mestring og lindring underveis i sykdomsforløpet (2).

Dette skillet har preget sykepleievitenskapen siden starten. Senere teorier har imidlertid bidratt til å nyansere bildet (3). Den nederlandske filosofen og etnografen Annemarie Mol belyser dette ved å vise til behandlingen av kronisk syke: Der medisinsk praksis ikke lenger kan love noen endelig kur, vil det å forskrive medisiner, å benytte tekniske hjelpemidler representere en praksis som likner omsorg. For Mol ligger det omsorg i å benytte teknologien på riktig måte. Omsorg handler om å tilpasse verktøyene til mennesket og situasjonen. Mols omsorg er like teknisk som den er varm og kjærlig, en omsorg som kanskje er spesifikk for legene, men ikke tilstrekkelig erkjent.

\section{Gjenerobre omsorgsbegrepet?}

Er så legenes omsorg å finne mellom den medisinske behandlingen og pleiesektorens profesjonsomsorg? Vi vet ikke hva legene sier om dette. Begrepet må få mening i den konteksten det benyttes. Det inngår for eksempel i helsepersonelloven uten at det gis noen klar betydning. I tillegg kan vi bare fornemme hva pasientene forventer og om disse forventningene står i konflikt med praksisens rammevilkår (4).

Legene må bli mer bevisst omsorgen i egen yrkesutøvelse slik at vi kan ta den til følge og diskutere den. Enkelte undersøkelser indikerer at legene ønsker en større profesjonell avstand til pasientene (5). Om det er slik, får kanskje forholdet mellom lege og pasient for mye oppmerksomhet. Andre studier indikerer at legene opplever at omsorgsliknende handlinger kommer i konflikt med helsevesenets effektivitets-

\section{«For mange leger er det kanskje nettopp omsorgen som gir arbeidet innhold og verdi»}

krav (6). Takstsystemene gir godtgjørelse for sårstell, blodprøver og samtaler, men det er mer lønnsomt for helseforetaket eller fastlegen å ta inn to pasienter på tiden man ville brukt på én. Noen vil hevde at omsorgen slører legens diagnostiske blikk, at den skaper falske forventninger til hva en lege skal være $(5,7)$ - forventninger som vanskeliggjør rollen som grensesetter og avstedkommer følelser av utilstrekkelighet og kognitiv dissonans $(8,9)$. Siden vi ikke vet hva leger og pasienter legger i omsorgsbegrepet, vet vi heller ikke hva som forventes. For mange leger er det kanskje nettopp omsorgen som gir arbeidet innhold og verdi.

Jeg sitter ikke med svarene. Men jeg mener vi trenger en diskusjon om legers omsorg. Den kan være under press. Den kan inngå i konflikter uten at vi makter å erkjenne det. Pasientene kan forvente en omsorg som legene ikke har rom for. Vi mangler kunnskap og et språk som gjør omsorgen synlig, og som gjør det mulig å sette den i sammenheng. Vi må øke bevisstheten rundt hva en lege skal være.

\section{Kim Dysthe}

kdysthe@me.com

Kim Dysthe (f. 1969) er allmennpraktiserende lege, tidligere fastlege ved Humana Sandvika medisinske senter.

Forfatter har fylt ut ICMJE-skjemaet og oppgir ingen interessekonflikter.

\section{Litteratur}

. Waerness K. The Rationality of caring. Econ Ind Democracy 1984; 5: 185-211.

2. Mol A, Moser I, Pols J. Care in practice. On tinkering in clinics, homes and farms. Bielefeld: Transcript Verlag, 2010

3. Mol A. The logic of care. Health and the problem of patient choice. London: Routledge, 2008.

4. Iliffe S. From general practice to primary care. The industrialization of family medicine. New York Oxford University Press, 2008.

5. Agledahl KM, Gulbrandsen P. Førde R et al. Courteous but not curious: how doctors' politeness masks their existential neglect. A qualitative study of video-recorded patient consultations. $J$ Med Ethics 2011; 37: 650-4.

6. Skirbekk H, Nortvedt P. Making a difference: a qualitative study on care and priority setting in health care. Health Care Anal 2011; 19: 77-88.

7. Mackenzie GM. The caring doctor is an oxymoron BMJ 1997; 315: 687-8.

8. Aronson E. Back to the future: retrospective review of Leon Festinger «A theory of Cognitive Dissonance. 1: An overview of the literature and its integration into theory and practice in clinical psychology. Br J Psychol 1998; 37: 341-53.

9. Hem E. Vi blir tilfreds til slutt. Tidsskr Nor Legeforen 2013; 133: 5.

Mottatt 14.3. 2013, første revisjon innsendt 29.3. 2013, godkjent 5.4. 2013. Medisinsk redaktør Hanne Støre Valeur.

Publisert først på nett. 